\title{
Lateral
}

JOURNAL OFTHE CULTURALSTUDIESASSOCIATION

Alexis de Coning, "Review of Measuring Manhood: Race and the Science of Masculinity, 1830-1934 by Melissa N. Stein (University of Minnesota Press)," Lateral 7.2(2018).

https://doi.org/10.25158/L7.2.18

This content is licensed under a Creative Commons Attribution 4.0 International License. Copyright is retained by authors.

Book Reviews

Issue 7.2 (Fall 2018)

\section{Review of Measuring Manhood: Race and the Science of Masculinity, 1830-1934 by Melissa N. Stein (University of Minnesota Press)}

\section{Alexis de Coning}

\begin{abstract}
Melissa N. Stein's Measuring Manhood tackles the complex intersections of race, gender, sexuality, and their attendant "sciences" across a century of US history. While the burgeoning fields of ethnology and sexology were equally prominent in Europe during this period, her focus on the US specifies the ways in which American "racial scientists" and sexologists differed from their European counterparts, as their research was often used to justify or bolster nationspecific cultural norms and legislation. The concept of masculinity was not simply a matter of "manhood" in the narrow sense, but carried with it a glut of other associations: humanity, civilization, citizenship, intelligence, morality, whiteness, cisgender heterosexuality, and middleclass restraint. Stein manages to convey the complexity and reciprocity of these constructions in each chapter with careful argumentation and ample examples.
\end{abstract}

Stein, Melissa N. Measuring Manhood: Race and the Science of Masculinity, 1830-1934. Minneapolis: University of Minnesota Press, 2015. ISBN 978-08166-7303-2. US List \$27 (paperback)

The publication of Measuring Manhood: Race and the Science of Masculinity, 1830-1934 seems almost prescient at this juncture in the history of the United States. The increased visibility of state violence against African Americans, the re-emergence and rise of white nationalism and identitarianism, and anxieties around immigration and citizenship over the last few years provide a contemporary backdrop for the book's historical investigation of race and masculinity in the US.

Melissa N. Stein's Measuring Manhood tackles the complex intersections of race, gender, sexuality, and their attendant "sciences" across a century of US history. While the burgeoning fields of ethnology and sexology were equally prominent in Europe during this period, her focus on the US specifies the ways in which American "racial scientists" and sexologists differed from their European counterparts, as their research was often used to justify or bolster nation-specific cultural norms and legislation-chattel slavery and lynching, for instance. Stein notes that the 1830 s provide the ideal turning point at which to begin her investigation: during the late eighteenth and early nineteenth centuries, European scientists "increasingly looked to the newly formed United States of America as a perfect laboratory for their theories about race," while American science was simultaneously "coming into its own" (11). Although Europe had "long seen a booming scientific literature on race dating back to the early modern period," (10) American ethnologists were respected in Europe, and the transatlantic exchange of ideas influenced ethnological thinkers across both continents; US racial scientists thus had a significant impact on European theories of racial difference. It is within this "perfect laboratory" that Stein traces the developments of scientific racism with extensive historical research, 
drawing on both primary and secondary sources to elucidate the constructions of normal and abnormal manhood.

Nonetheless, as the socio-political landscape became more contentious, the axioms of ethnology evolved over time with racial scientists adapting their theories and findings to respond to the changing positions of African Americans and women in US society. Importantly, Stein foregrounds the pervasiveness of gender and sexuality within racescience discourses and their temporal shifts. Despite the assumption that racial disparity constituted an exclusive focus for many ethnological scientists, questions of racial difference, sex, gender, and reproduction were often invoked-either implicitly or explicitly-to maintain arguments about the superiority of Anglo-Saxon men, and the concomitant inferiority of African Americans, women, other non-white Europeans, and immigrants. For these racial scientists and sexologists, then, the stakes of their investigations were to prove and naturalize the gendered and racial hierarchies (and, by extension, inequalities) that were being challenged at various points by abolitionists, suffragist movements, the National Association for the Advancement of Colored People (NAACP), and occasionally from within the discipline of ethnology itself. The concept of masculinity was therefore not simply a matter of "manhood" in the narrow sense, but carried with it a glut of other associations: humanity, civilization, citizenship, intelligence, morality, whiteness, cisgender heterosexuality, and middle-class restraint. Stein manages to convey the complexity and reciprocity of these constructions in each chapter with careful argumentation and ample examples.

The book moves chronologically, with each chapter honing in on a prominent racial scientists or a specific problem. However, even though different racial scientists' concerns and anxieties shifted over the century, the different chapters often bleed into each other, reflecting the intellectual continuity and overlaps among each of the figures discussed. In "Races of Men," Stein begins her exploration of racial science and masculinity with antebellum ethnology. This first chapter presents the pioneers of US ethnology as preoccupied with the question of original unity or diversity; in other words, did the different races emerge from one common ancestor, or were they in fact separate species? As Stein demonstrates from this question, antebellum ethnologists were thus focused on less "sex-specific characteristics" like bones and skin; however, their inquiries were not gender-neutral, with racial scientists positing the white male as the default subject, and conceptualizing race in terms of "male lineages and patriarchal destinies" (29). However, in the second chapter, "An Equal Beard for Equal Voting," Stein shows how Civil War racial scientists' continued use of the white male body as normative became more overtly gendered, with beards and body hair signaling white men's aptitude for both manhood and citizenship. Furthermore, the trope of the hypersexual black man was legitimized by ethnologists and physicians at this time-establishing the discourse of African-American masculinity as excessive and unruly.

It is thus interesting that by the turn of the century, the "abnormality" of black sexuality becomes a foil to white sexuality in a different context-that of "inverts" and homosexuals. In Chapter 3, "Inverts, Perverts, and Primitives," Stein elucidates the links among sexology, racial thought, and class politics from roughly 1890 to the 1920 s. Black, immigrant, and working-class sexualities were already seen as degenerate; homosexuality and non-normative gender expressions in these groups were to be expected (albeit deplored) and interpreted as a moral failing on the part of individuals. For middle-class whites, however, "inversion" was typically framed as congenital-an affliction that could not be helped, although it did contribute to "race suicide." (214) Stein then turns our attention back to the stereotyping of African American men as oversexed in the fourth chapter, "Unsexing the Race." Here she tackles debates around lynching and castration 
during the same period as the previous chapter, further demonstrating the overlaps between sexual and racial sciences. Moreover, she highlights the "intersection between science and the street," (219) as scientific and public discourses on race, biological essentialism, and black hypersexuality were largely indistinguishable from one another. In the final chapter, "Walter White, Scientific Racism, and the NAACP Antilynching Campaign," Stein focuses on the work of NAACP leader Walter White in the late 1920s. White's Antilynching Campaign leveraged strategic relationships with white scientists to challenge the public discourse undergirded by racial science and biological determinism at a pivotal and transitional moment.

However, it should be noted that Stein also includes instances of people who challenged these discourses throughout the book-drawing attention to the dissenting voices that have existed alongside the mainstreaming of ethnology since its inception. She underscores that while ethnological theories were often treated as cutting-edge science, contemporary critics also resisted the pseudoscience of ethnology. Furthermore, Stein's own tone performs a similar function at various points throughout the book. For example, ethnologist Samuel Cartwright compared the sleeping habits of African Americans to infants, arguing that both groups "instinctively" cover their faces while sleeping. Here Stein remarks that one "presumes that Cartwright must have traveled extensively and suffered considerable insomnia to have had the opportunity to witness enough babies and African Americans in slumber to declare face covering to be universal among both" (7677). Moments like these provide a much-needed undercutting of the apparent gravitas of ethnological theory and the litany of examples of white men's supposed intellectual superiority.

This book would make a strong addition to syllabi in history, cultural studies, gender and women's studies, masculinity studies, and ethnic studies classes, as well as discussions of biopolitics and medical-scientific discourses in the US. Stein's writing is engaging, vivid, and uncluttered. There is no dense theoretical labyrinth to navigate before encountering the crux of her research: the co-construction of race and masculinity over a century of US history. In this way, Measuring Manhood is convincing and thoroughly engrossing from the first chapter to the last.

․ㅡㅅㅜ

Alexis de Coning

Alexis de Coning is a PhD student in the College of Media, Communication and Information at the University of Colorado Boulder. She studies the history and media practices of the men's rights movement. More broadly, her research interests include masculinity, social movements, online communities, and the intersections of Marxism and feminism. 